\title{
Portrait of Global Civil Society at the Bretton Woods Institutions:
}

\author{
Civil Society Dialogue Participation, 2000-2007*
}

\author{
Robert E. Kelly \\ (Pusan N ational University)
}

\section{$\langle$ CONTENTS〉}

I. Data Challenge of Studying NGOs

II. History of BWI-NGO Interaction

III. Civil Society Dialogues

IV. Coding

V. NGOs at the BWI

1. Who Comes $\cdots$

2. From Where $\cdots$

3. To What Kinds of Meetings?

4. Aggregate Portrait
VI. Global Governance at the BWI

1. Decline

2. Northern Domination?

3. Breach with the Fund

4. Theory: A Coopted Epistemic Community

VII. Future of CSDs

- Keyword: Nongovernmental Organization/NGO, International Monetary Fund, World Bank, Global Civil Society

\section{【ABSTRACT】}

Good records of who exactly populates global civil society are sparse. This gap inhibits induction from data to theory, driving the complaint that the NGO literature is ideographic. Macro datasets from the Union of International Associations and UN Economic and Social Council are broad. But the World Bank and IMF retain richer data on NGO attendance and participation at their biannual "civil society dialogues." Where UIA and ECOSOC simply track existence, these data track behavior, permitting clearer inductive inference. The Bank/Fund data

\footnotetext{
*This work was supported by a Pusan National University Research Grant, 2008. Portions of the following research were formally presented to the Bretton Woods Institutions on September 13, 2005. I would like to thank the civil society staff of the Bank and Fund for their assistance in collecting the data analyzed here, especially Jeremy Mark and John Garrison. Special thanks also go to my research assistant, Prakash Vemulapalli, for the data manipulation. Finally, I would like to thank Chadwick Alger, Alexander Thompson, William Liddle, and the anonymous reviews of the KJIR for their many helpful comments.
} 
reveal regular but declining commitment by a limited number of mostly Northern INGOs around one primary issue - debt-and three secondary ones - globalization, transparency, and health. A coopted but genuinely transnational epistemic community of routinely interacting BWI and NGO officials has emerged.

Robust quantitative data-sets on international nongovernmental organizations (I/NGOs) in global civil society (GCS) are rare. NGO research must frequently rely on case studies, and this inhibits generalizable theoretical induction. Further, researchers' grounds for the selection of specific cases raise well-known criticisms and validity threats. Critics contend that researchers select only successful campaigns or those close to the normative preferences of the researcher." Few broader lessons can be drawn from such limited and contested narratives. The need for large-n datasets is now clearly in

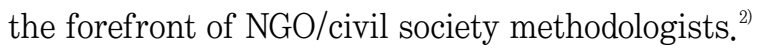

This research responds to these concerns with the presentation of a new quantitative dataset of NGOs around the Bretton Woods Institutions (BWI - the World Bank and International Monetary Fund [IMF]). It presents time-series data of NGO attendance at topical meetings (Civil Society Dialogues) at biannual conferences between NGOs and BWI officials from 2000-2007. It tracks which NGOs came to which meetings, in what numbers, and how often. This provides a greater level of detail than is available in datasets such as the Union of International Associations' (UIA) Yearbook of International Organization or the United Nations' (UN) Economic and Social Council (ECOSOC) roster. Those simply list groups. By contrast, this new dataset drills down further. It can longitudinally demonstrate, e.g., the top NGO participants on given themes, or the intensity of NGO commitment measured by attendance fluctuation.

This data resolves the above-mentioned validity threats. All NGOs in attendance are recorded, according to data provided by the NGO offices of the Bank and Fund. This

1) Thomas Risse, "Transnational Actors and World Politics," in Walter Carlsnaes, Risse and Beth Simmons, eds., Handbook of International Relations (London: Sage, 2002): 255-274; Kenneth Anderson and David Rieff, "Global Civil Society: A Skeptical View," in: Marlies Glasius, Mary Kaldor and Helmut Anheier, eds. Global Civil Society 2004/5 (London: Sage): 26-39.

2) The annual Global Civil Society Yearbook (http://www.lse.ac.uk/Depts/global/yearbook.htm) publishes regular methodology chapters; Kathryn Sikkink and Jackie Smith, "Infrastructures of Change: Transnational Organizations, 1953-93," in, Sanjeev Khagram, James Riker, and Sikkink, eds,. Restructuring World Politics (Minneapolis: University of Minnesota Press, 2002): $24-44$. 
also opens the possibility of richer and generalizable inductive theorizing on NGOs. The essay will continue as follows. First, a methodological discussion of identifying relevant NGOs in world politics culminates in an argument for this dataset. Second, the data is presented with graphical depictions of the NGO universe around the BWI. Third, an analysis concludes that NGO engagement at the BWI is declining, especially at the Fund, into a professionalized but coopted epistemic community.

\section{I . Data Challenge of Studying NGOs}

INGOs have been active for a least a century, but tracking them has proven frustratingly difficult. This drives the oft-made complaint that the NGO literature is too idiosyncratic, case-based, and anecdotal. ${ }^{3)}$ This criticism places the cart before the horse. NGO researchers have struggled for decades to find or build quantitative datasets. However, information is routinely poor. In the dominant paradigms of international relations, NGOs are anomalies, so data are not collected as vigorously. ${ }^{4)}$ Nor do 'free-spirited' NGOs collaborate much. Part of their shared dislike of establishment thinking is a resistance to the formalism of social science tracking. ${ }^{5}$

Hence NGO scholarship frequently fell into documenting single groups or campaigns. ${ }^{6}$ In the haste to demonstrate that NGOs were not just anomalies, successful campaigns or groups were usually chosen for analysis. In turn, this fed the criticism of selection on the dependent variable (only successful NGOs are examined) and the politicization of scholarship.

Recently, the availability of datasets has improved. NGO researchers have taken more seriously the need for quantitative data. ${ }^{7)}$ The Global Civil Society Yearbook consistently

3) Randall Schweller and Ted Hopf, in personal conversation; Risse, "Transnational Actors;" Sikkink and Smith, "Infrastructures for Change," 24.

4) Margaret Karins and Karen Mingst, International Organizations (Boulder: Lynne Rienner, 2004): 241.

5) Antonio Donini, "Bureaucracy and the Free Spirits: Stagnation and the Innovation in the Relationship Between the UN and NGOs," in Thomas Weiss and Leon Gordenker, eds., NGOs, the UN and Global Governance (Boulder: Lynne Rienner, 1996): 83-101; Robert Kelly, "Impact of NGOs on the Bretton Woods Institutions - Executive Summary," (Washington: World Bank, 2006), available at http://web.worldbank.org/WBSITE/EXTERNAL/TOPICS/CSO/0,, contentMDK: 20127029 menuPK:277368 pagePK:220503 piPK:220476 theSitePK:228717,00.html.

6) Robert Keohane and Joseph Nye, eds. Transnational Relations and World Politics (Cambridge: Harvard UP, 1971); Ann Florini, ed., Third Force: The Rise of Transnational Civil Society (Washington: Carnegie Endowment, 2000).

7) Daniel Nielson and Michael Tierney, "Delegation to International Organizations," International 
publishes methodological analyses for the study of INGOs. The UIA Yearbook is widely accessible through the internet, ${ }^{8)}$ and its presentation and coverage of NGOs, as distinct from IOs, has improved dramatically in the last two decades. Finally, ECOSOC has taken to publishing its roster of accredited NGOs, and the UN Nongovernmental Liaison Service and Congress of NGOs at the UN provide more information than ever before, although it still requires greater quantification. ${ }^{9}$

Unfortunately, no NGO-driven global clearing house exists. Neither the Congress of NGOs $^{10)}$ nor the World Social Forum process ${ }^{11)}$ have successfully built a global leadership role among INGOs; GCS remains fragmented, which reflects the antihierarchical nature of many NGOs. Hence, NGO tracking is still left up to external researchers, prompting another validity issue: NGOs may question the presentation of results about themselves by third parties. Nevertheless, large-n quantification should reduce over time the more pressing social science issues of selection bias and researchers' personal politics. Not all the NGOs on the ECOSOC roster, e.g., will be efficacious advocates. Some will fail, and large-n sets will capture this. Such sets should be less discriminatory and more generalizable.

This essay builds on this history. This data presentation further refines our large-n quantitative portrait of NGOs in GCS. The UN and UIA datasets are global and broad. They capture NGOs all over the planet with only minimal restrictions for inclusion. A clear improvement over idiosyncratic selection, they nonetheless provide little detail. NGO researchers seeking to examine solely the "social change INGOs ${ }^{122}$ " in GCS will still struggle to pull much out of them. Louis Kriesberg and Peter Willetts have both noted, e.g., that many NGOs in GCS are nonpolitical or alltaeglich. ${ }^{13)}$ Filtering this out requires another level of coding.

Kathryn Sikkink and Jackie Smith offer such an analysis and provide the starting point for the work presented in this essay. ${ }^{14)}$ They begin with the UIA list, but sharpen their portrait of GCS to social change NGOs (as distinct from UIA's criteria of simply

Organization 57/2 (2003): 271.

8) http://www.uia.be/yearbook.

9) http://www.un.org/esa/coordination/ngo/about.htm.

10) http://www.ngocongo.org/.

11) http://wsf2007.org/.

12) Sikkink and Smith, "Infrastructures for Change," 25.

13) Kriesberg, "Social Movements and Global Transformation," in, Jackie Smith, Charles Chatfield, and Ronald Pagnucco, eds., Transnational Social Movements and Global Politics (Syracuse: Syracuse UP, 1997): 3-18; Willetts, "Pressure Groups as Transnational Actors," in, Willetts, ed., Pressure Groups in the Global System (NY: St. Martin's Press, 1982): 1-27.

14) "Infrastructures for Change." 
any organization with three or more chapters in different countries). The Yearbook finds almost 23,000 active INGOs in 2004, ${ }^{15)}$ but Sikkink and Smith's fine-grain coding uncovered less than 1000 meaningful social change NGOs. These they divide along issue lines into roughly six groups-human rights, peace, women's rights, environment, international law, and development. Nearly half of the groups fall in the human rights and environment categories. They also code social change NGOs by geographical dispersal, finding, unsurprisingly, that groups from the global North represent the bulk of politically active GCS.

The following data presentation parallels and deepens their effort. First, I too code by issue area and geography. But the Bank and Fund have saved richer information on their NGO engagement. Their data permit a portrait of behavior around specific issues beyond the scope of the UIA Yearbook.

Second, I also accept the argument of Sikkink and Smith's coauthors that international organizations (IO) are an excellent arena for tracking NGOs. ${ }^{16)}$ Global governance is weak and poorly formed. ${ }^{17}$ There is no state-like body in world politics around which INGOs easily accrete, as interest groups do in national polities. Instead, politically active INGOs cluster around IOs. IOs play a (reverse) constitutive role for the political active portion of NGOs in GCS. ${ }^{18)}$ That community is not sui generis. If the issues Sikkink and Smith identify-human rights, development, etc. - were regulated solely at the national level, NGOs would not scale up. But as globalization pushes policy toward transnational processes and institutions, NGOs have followed. ${ }^{19)}$ IOs that embody relevant issues then become lightning rods around which transnational coalitions or communities of NGOs bond.

Finally, some IOs are weaker than others, so NGO behavior is more relevant at some IOs than others. The Bank and Fund, for reasons of binding conditionality, great power interest, and large spending flows, are the most efficacious IOs in the UN system. ${ }^{20}$

15) http://www.uia.org/statistics/organizations/types-2004.pdf.

16) Sanjeev Khagram, James Riker, and Kathryn Sikkink, "From Santiago to Seattle: Transnational Advocacy Groups Restructuring World Politics," in, Khagram, Riker, and Sikkink, eds. Restructuring, 11. Also, Karns and Mingst, International Organizations, 230.

17) Morten Ougaard, and Richard Higgott, eds. Towards a Global Polity (NY: Routledge, 2002).

18) William Coleman and Sarah Wayland, "Origins of Global Civil Society and Nonterritorial Governance," Global Governance, 12/3 (2006): 241-61.

19) Jan Scholte, "Civil Society and the Legitimation of Global Governance," Center for the Study of Globalization and Regionalization, University of Warwick, Working Paper 223/07, March 2007, 5-6, 12.

20) Robert O'Brien, Anne Marie Goetz, Jan Aart Scholte, and Marc Williams, Contesting Global Governance (Cambridge: Cambridge UP, 2000); Deepak Nayyar, ed., Governing Globalization, (Oxford: Oxford UP, 2002). 
They represent critical cases from which to begin, and they keep increasingly robust data on NGO attendance at internal meetings.

\section{II . History of BWI-NGO Interaction}

This essay presents the data of the BWI on the attendance of NGOs at their biannual meetings. The World Bank and IMF hold shareholders meetings twice a year. The Annual Meetings in the autumn, usually in September or October, are the formal yearly convocation of the BWI boards of governors. Beginning in 1997, a second, working meeting began occurring in the spring (usually in April). The spring meetings always occur in Washington DC. The annual meetings rotate every third year outside of Washington. In the relevant time period of the dataset presented here, the 2000 annuals were in Prague; 2003's were in Abu Dubai; and 2006's were in Singapore.

The collapse of the Cold War unleashed large parts of the global economy. Globalization subsequently accelerated in the 1990s, and the need for global rules, "global governance" (GG), became increasing clear. ${ }^{21)}$ Few robust IOs existed to provide the necessary arena for such coordination. The efficacious BWI, for reasons mentioned above, quickly became the central (and overwhelmed) pillars of the "international financial architecture" (IFA). Hence the relevance of the Spring and Annual Meetings increased. They became a central feature in an emerging, albeit rickety, global public policy process. ${ }^{22)}$

If globalization empowered first sector, profit-seeking firms, it also opened space for third sector non-profits to link up across borders. With the expansion of economic activity across borders came wider transnational social exchange. As corporations increasingly transnationalized, so too did civil society. (Only the second, public sector, resisted; states, the foremost public sector actor, are wedded to territoriality and resist the upward globalization of their authority to the UN or agencies similar to the BWI. This has badly crippled the IFA's ability to respond meaningfully to crises such as East Asia and more generally forge acceptable rules for all in the global economy. ${ }^{23}$ )

Global civil society (GCS) congealed in the 1990s. ${ }^{24)}$ It comprises many actors, some of whom are wholly unpolitical. Alltaeglich non-profit sectors, like sports, entertainment/

21) Nayyar, Governing Globalization; Commission on Global Governance, Our Global Neighborhood (Oxford: Oxford UP, 1995).

22) Ougaard and Higgott, Global Polity; Rorden Wilkinson and Steve Hughes, eds., Global Governance (London: Routledge, 2002); Scholte, "Civil Society and Legitimation," 4-5.

23) Joseph Nye, Paradox of American Power (New York: Oxford, 2003): 46.

24) Paul Wapner, "Governance in Global Civil Society," in Oran Young, ed., Global Governance 
hobbies, and professions have all scaled up to the global level too. Yet of most relevance to international politics is the emergence of robust, social change NGOs. In the 1990s, these were mostly on the political left (although this picture is changing now ${ }^{25}$ ). Widely termed the antiglobalization movement, ${ }^{26)}$ it is better understood left-critical, or "globalisierungskritisch. ${ }^{27}$ " Radical antiglobalizers constitute the left wing of the movement, but there are also moderate, social welfarist critics. Jan Scholte speaks of the division between reformists seeking to soften neoliberalism and radicals seeking to overturn the IFA altogether. ${ }^{28)}$

These politically active, left-critical INGOs emerged from GCS to dispute the IFA's authority over international economics. They scored a major success in helping overturn the Multilateral Agreement on Investment (MAI) in the late 1990s. In 1999, an alliance of labor and left-critical NGOs from GCS derailed the Seattle meeting of the World Trade Organization. ${ }^{29)}$ By 2000, it appeared that an emerging counter-globalization front could put tens of thousands of people on the street at any meeting of the IFA global policy circuit. ${ }^{30)}$ The Bank and Fund, which had already seen protests as early as the 1980s, sought to defuse this emerging resistance by opening their first formal dialogues with transnational civil society groups at the Prague annual meetings of 2000.

The meetings were chaotic but reasonably conciliatory. For the NGOs, they opened new doors of access but raised problems of cooptation. ${ }^{31)}$ For the Bank and Fund, they were a manner to defuse a rising coalition of (mostly) leftist groups that increasingly threatened the institutions' very survival. BWI staff were stunned at how quickly the coalition arose in the 1990s and its considerable sympathy in Northern electorates. ${ }^{32)}$ In spring 2001, the BWI held another series of civil society dialogues parallel to its primary meetings of the member-states. With this began a pattern of parallel "Civil Society Dialogues" (CSDs) alongside the central meetings in the spring and fall.

(Cambridge: MIT Press, 1997): 65-84.

25) Martin Albrow and Helmut Anheier, "Violence and the Possibility of Global Civility," in: Anheier, Mary Kaldor, and Marlies Glasius, eds. Global Civil Society 2006/7 (London: Sage): $1-17$.

26) Jagdish Bhagwati, In Defense of Globalization (Oxford: Oxford UP, 2005).

27) Knud Voecking of Urgewald (INGO), personal conversation, 2004.

28) Scholte, "Civil Society and Democracy in Global Governance," Global Governance, 8/3 (2002): 281-304.

29) Robert Gilpin, Global Political Economy (Princeton: Princeton UP, 2001): 393-96.

30) http://www.ifiwatchnet.org/?q=en/frontpage.

31) Jan Scholte, "Civil Society and IMF Accountability," Center for the Study of Globalization and Regionalization, University of Warwick, Working Paper 244/08, May 2008.

32) Interviews conducted at the BWI, June-July 2004. 


\section{Civil Society Dialogues}

These CSD are now routine, having occurred at every spring and annual meeting, but for the cancelled annuals of 2001, since the 2000 annual. Months beforehand, the IMF'S Policy Communications Division and the World Bank's Civil Society Team solicit NGO input on possible topics. ${ }^{33)}$ A series of seminars in the BWI buildings in Washington, or the requisite meeting site abroad, are arranged over roughly the one week of the meetings. Recently the Bank has started terming the CSDs, as a bloc, the "Civil Society Policy Forum." Such parallel conferencing is common. The World Social Forum began similarly. Occasionally there are street protests in tandem with the meetings and CSDs, but this has slackened substantially since 9/11.

The Bank and Fund NGO staff circulate sign-in sheets at these meetings. These provide the relevant information to drill downward toward specific groups' concerns for specific issues. Under the meeting title are listed participants with their affiliations (individual names have been redacted). I have collated these data into a spreadsheet with the year, meeting set (spring or annual), and title of the CSD in the columns, cross-referenced against the name of the NGO in the rows. In the cells is a numeric value representing the number of meeting attendees from a given NGO ${ }^{34}$

At two meeting sets - the annuals of 2000 (Prague) and 2003 (Abu Dubai) - the BWI had no listing of NGO attendance at specific CSDs, only listings of those that came to the event as whole, and how many individuals from an organization attended. Fortunately, that still leaves 80 individual CSDs at the Bank and 45 at the Fund over seven years. (Hence, the total number of meetings are listed at 82+ [WB] and 47+ [IMF]). Almost 400 NGOs across both institutions have attended at least one meeting.

\section{Coding}

Because the CSDs are open to anyone in GCS, there are inevitably coding choices. I am examining groups akin to Kriesberg's "transnational social movement organizations" (TSMOs) or Sikkink and Smith "social change NGOs." To avoid the labeling disputes, I have simply termed these groups NGOs. It is an imprecise term, indicating almost anything unaffiliated with government, but it is the term in currency. Expressions like

33) http://web.worldbank.org/WBSITE/EXTERNAL/TOPICS/CSO/0,, contentMDK:21426033 page PK:220503 piPK:220476 theSitePK:228717,00.html\#Accreditation.

34) The spreadsheet is available in excel format upon request at rekelly@pusan.ac.kr. 
TSMOs and TANs (transnational advocacy network) simply have not taken hold. ${ }^{35)}$ But not all the attendees at the CSDs are NGOs. Several classes of attendant civil society and other actors are excluded.

My coding of NGOs follows the rules and definitions laid out in an earlier essay. ${ }^{36}$

First, NGOs are non-profit. This distinguishes them from MNCs, and epistemic communities and TANs, which can include parts of the state and IOs. Whether MNCs are a part of GCS is unclear, but non-profit status captures the social and popular element of NGO activism. Second, NGOs self-understand as principled or value-based actors. Automatically this excludes many of Peter Willetts' sectional and professional groups which are usefully classified as separate categories of private actors in GCS. ${ }^{37)}$ Third, NGOs actively promote social change. This narrows our definition toward TSMOs, but does not impose its high expectations of either progressive, left-leaning politics or transnational membership or scope. The NGOs IR theory cares about are not so much umbrella professional organizations or cross-national recreational organizations, but those that act explicitly as agents on the international stage competing with states, IOs, and MNCs for policy and ideational change. These may also be nationalized or 'regressive.' ${ }^{38)}$

These criteria are explicitly few and light to avoid controversies over exclusion, yet they do screen out many groups that are in GCS, but which few scholars would term NGOs.

Applying these rules to the specifics of this dataset filters out the following: First, following Moses Naim, ${ }^{39)}$ GONGOs (Government-Operated NGOs) are excluded. This is a tough choice on the particular issue of the German Stiftungen, such as the FriedrichEbert-Stiftung. ${ }^{40)}$ But they are explicitly tied to political parties and receive significant funding from the state.

35) During field research I have tried out these various expressions on NGO staff, and broadly found bewilderment. "Civil society" and "NGO" are the relevant self-descriptors, and I work within that constraint. "TAN" is from Margaret Keck and Kathryn Sikkink, Activists Beyond Borders (Ithaca: Cornell UP, 1998).

36) Robert Kelly, "From IR to Global Governance Theory," Journal of Civil Society, 3/1 (2007): 81-99.

37) Willetts, "Pressure Groups."

38) Mary Kaldor, Helmut Anheier, and Marlies Glasius, "Global Civil Society in an Era of Regressive Globalization," in: Glasius, Kaldor and Anheier, eds., Global Civil Society 2003 (London: Sage): $3-33$.

39) Moses Naim, "What is a Gongo?" Foreign Policy, 160 (2007): 95-96.

40) http://www.fes.de/. 
Second, where possible think-tanks were retained. On investigation, if the institution is a state-run or dominated GONGO, it was excluded. But many are private, and many Southern NGOs in attendance styled themselves in this manner.

Third, unions were excluded. This follows the precedent of the International Labor Organization, the GCS Yearbook, and the language of NGOs and union representatives at the CSDs themselves. All agree that NGOs and unions are distinct. Like the Stiftungen, this was a difficult exclusion, because officials from International Trade Union Confederation were frequently at the Dialogues.

Three other coding issues deserve mention. First, attendees were assigned their NGO affiliation by the group name they provided. Many NGOs, especially in the South, belong to networks or coalitions creating overlapping identities that could inflate the number of attendees. Interaction, e.g., is a collection of 165 NGOs. Hence I simply use that title the attendee provided.

Second, in coding an NGO by state and region, I used the location of its headquarters or secretariat. ${ }^{41)}$ This benchmark is growing problematic. The data shows that NGOs are increasingly transnational and networked. This diffuses authority and reflects NGOs' general dislike for excessive hierarchy. Nevertheless, there is deep, continuing suspicion that NGO coalitions are heavily slanted toward Northern elites. "Sociologically, the civil society that engages the IMF generally mirrors rather than counters social hierarchies in global politics at large. ${ }^{42)}$ " Hence, NGOs were coded by eight regions, as well as the North-South macro-region. The regions are: North America, Latin America/ Caribbean, Western Europe and Australia, Eastern Europe, Africa, Middle East, South Asia, and the East Asia.

Third, following Sikkink and Smith's reduction of NGOs into six topical categories, the CSDs were also coded into such categories. They are: (meetings about) individual countries and regions, globalization/development policy, development financing and the private sector, aid and debt, health, poverty, environment/energy/infrastructure/industry, rules governing IFI instruments, trade, and transparency/oversight/accountability/BWI governance. These categories, although a bit unwieldy, capture the range of discussion between BWI and NGO staff.

41) Helmut Anheier and Hagai Katz, "Mapping Global Civil Society," Marlies Glasius, Mary Kaldor and Anheier, eds., Global Civil Society 2003 (London: Sage): 241-258.

42) Scholte, "Civil Society and IMF," 15. 


\section{NGOs at the BWI}

\section{Who Comes $\cdots$}

The following is the data portrait of NGOs at the World Bank and IMF. In the time frame provided, 358 NGOs attended at least 82 meetings at the Bank, and 287 attended at least 47 at the Fund. I have broken the data down by 'performance' - how many meetings

Chart 1a: Top NGO Performers, by Meeting Attendance, World Bank

\begin{tabular}{|l|c|l|c|}
\hline \multicolumn{1}{|c|}{ NGO } & $\begin{array}{c}\text { \# of CSDs } \\
\text { Attended }\end{array}$ & \multicolumn{1}{|c|}{ Region } & $\begin{array}{c}\text { Macro- } \\
\text { Region }\end{array}$ \\
\hline Bank Information Center & 40 & North America & $\mathrm{N}$ \\
\hline World Vision & 35 & North America & $\mathrm{N}$ \\
\hline Action Aid & 28 & North America & $\mathrm{N}$ \\
\hline Jubilee 2000 Network & 28 & North America & $\mathrm{N}$ \\
\hline Oxfam International & 28 & North America & $\mathrm{N}$ \\
\hline Save the Children & 28 & North America & $\mathrm{N}$ \\
\hline $\begin{array}{l}\text { European Network on Debt and } \\
\text { Development (EURODAD) }\end{array}$ & 28 & Western Europe \& Australia & $\mathrm{N}$ \\
\hline InterAction & 27 & North America & $\mathrm{N}$ \\
\hline Bretton Woods Project & 24 & Western Europe \& Australia & $\mathrm{N}$ \\
\hline Christian Aid & 20 & Western Europe \& Australia & $\mathrm{N}$ \\
\hline Center of Concern & 19 & North America & $\mathrm{N}$ \\
\hline $\begin{array}{l}\text { Campagna per la riforma della } \\
\text { Banca mondiale }\end{array}$ & 18 & Western Europe \& Australia & $\mathrm{N}$ \\
\hline Catholic Relief Services & 17 & North America & $\mathrm{N}$ \\
\hline Environmental Defense Fund & 14 & North America & $\mathrm{N}$ \\
\hline Social Justice Committee & 13 & North America & $\mathrm{N}$ \\
\hline World Economy, Ecology and Development & 13 & Western Europe \& Australia & $\mathrm{N}$ \\
\hline Friends of the Earth & 12 & North America & $\mathrm{N}$ \\
\hline Korach Civil Society Forum & 12 & Middle East & $\mathrm{N}$ \\
\hline $\begin{array}{l}\text { Catholic Fund for Overseas } \\
\text { Development (CAFOD) }\end{array}$ & 11 & Western Europe \& Australia & $\mathrm{N}$ \\
\hline Third World Network & 10 & Nast Asia & $\mathrm{S}$ \\
\hline Citizens Network of Essential Services & 10 & Western Europe \& Australia & $\mathrm{N}$ \\
\hline Halifax Initiative & Western Europe \& Australia & $\mathrm{N}$ \\
\hline Broederlijk Delen & 10 & Western Europe \& Australia & $\mathrm{N}$ \\
\hline $\begin{array}{l}\text { Cooperation International pour } \\
\text { la Developpement et la Solidarite (CIDSE) }\end{array}$ & \begin{tabular}{l} 
North America \\
\hline $\begin{array}{l}\text { Norwegian Campaign for the Cancellation } \\
\text { Of Third World Debt (SLUG) }\end{array}$
\end{tabular} & 10 & $\mathrm{~N}$ \\
\hline
\end{tabular}


Chart 1b: Top NGO Performers, by Meeting Attendance, IMF

\begin{tabular}{|c|c|c|c|}
\hline NGO & $\begin{array}{l}\text { \# of CSDs } \\
\text { Attended }\end{array}$ & Region & $\begin{array}{l}\text { Macro- } \\
\text { Region }\end{array}$ \\
\hline Bretton Woods Project & 23 & Western Europe \& Australia & $\mathrm{N}$ \\
\hline Jubilee 2000 Network & 23 & North America & $\mathrm{N}$ \\
\hline Action Aid & 21 & North America & $\mathrm{N}$ \\
\hline Oxfam International & 21 & North America & $\mathrm{N}$ \\
\hline World Vision & 21 & North America & $\mathrm{N}$ \\
\hline Center of Concern & 19 & North America & $\mathrm{N}$ \\
\hline $\begin{array}{l}\text { European Network on Debt and } \\
\text { Development (EURODAD) }\end{array}$ & 19 & Western Europe \& Australia & $\mathrm{N}$ \\
\hline Save the Children & 17 & North America & $\mathrm{N}$ \\
\hline Bank Information Center & 16 & North America & $\mathrm{N}$ \\
\hline Christian Aid & 15 & Western Europe \& Australia & $\mathrm{N}$ \\
\hline Social Justice Committee & 14 & North America & $\mathrm{N}$ \\
\hline Trocaire & 14 & Western Europe \& Australia & $\mathrm{N}$ \\
\hline Friends of the Earth & 13 & North America & $\mathrm{N}$ \\
\hline $\begin{array}{l}\text { African Forum and Network on } \\
\text { Debt and Development (AFRODAD) }\end{array}$ & 12 & Africa & S \\
\hline $\begin{array}{l}\text { Campagna per la riforma della } \\
\text { Banca mondiale }\end{array}$ & 12 & Western Europe \& Australia & $\mathrm{N}$ \\
\hline World Economy, Ecology and Development & 12 & Western Europe \& Australia & $\mathrm{N}$ \\
\hline $\begin{array}{l}\text { Cooperation International pour la } \\
\text { Developpement et la Solidarite (CIDSE) }\end{array}$ & 11 & Western Europe \& Australia & $\mathrm{N}$ \\
\hline InterAction & 11 & North America & $\mathrm{N}$ \\
\hline Debt and Development Coalition & 10 & Western Europe \& Australia & $\mathrm{N}$ \\
\hline New Rules for Global Finance Coalition & 10 & North America & $\mathrm{N}$ \\
\hline $\begin{array}{l}\text { Norwegian Campaign for the Cancellation } \\
\text { of Third World Debt (SLUG) }\end{array}$ & 10 & Western Europe \& Australia & $\mathrm{N}$ \\
\hline $\begin{array}{l}\text { Catholic Fund for Overseas Development } \\
\text { (CAFOD) }\end{array}$ & 9 & Western Europe \& Australia & $\mathrm{N}$ \\
\hline Third World Network & 9 & East Asia & $\mathrm{S}$ \\
\hline Catholic Relief Services & 8 & North America & $\mathrm{N}$ \\
\hline Evangelischer Entwicklunsdienst & 8 & Western Europe \& Australia & $\mathrm{N}$ \\
\hline
\end{tabular}

were attended by at least one member of an NGO. Chart 1 (a: Bank; b: Fund) lists the top 25 NGOs, by the number of meetings attended.

Chart 2 lists the number of NGO staff in attendance. Chart 1 suggests the breadth of NGO interest-how many different meetings were attended? Chart 2 suggests the intensity of interest - what is the absolute number of staff sent? The top 25 of Charts 1 and 2 are very similar. Of the 100 NGOs listed in the Charts 1 and 2, only six come from 
the South

Chart 2a: Top NGO Performers, by Attendance Intensity, World Bank

\begin{tabular}{|c|c|c|c|}
\hline NGO & $\begin{array}{c}\# \text { of } \\
\text { Attendees }\end{array}$ & Region & $\begin{array}{l}\text { Macro- } \\
\text { Region }\end{array}$ \\
\hline Bank Information Center & 113 & North America & $\mathrm{N}$ \\
\hline Jubilee 2000 Network & 85 & North America & $\mathrm{N}$ \\
\hline Oxfam International & 85 & North America & $\mathrm{N}$ \\
\hline World Vision & 65 & North America & $\mathrm{N}$ \\
\hline Save the Children & 57 & North America & $\mathrm{N}$ \\
\hline Friends of the Earth & 50 & North America & $\mathrm{N}$ \\
\hline InterAction & 49 & North America & $\mathrm{N}$ \\
\hline Action Aid & 45 & North America & $\mathrm{N}$ \\
\hline $\begin{array}{l}\text { European Network on Debt and } \\
\text { Development (EURODAD) }\end{array}$ & 40 & Western Europe \& Australia & $\mathrm{N}$ \\
\hline Bretton Woods Project & 28 & Western Europe \& Australia & $\mathrm{N}$ \\
\hline Christian Aid & 25 & Western Europe \& Australia & $\mathrm{N}$ \\
\hline Center of Concern & 22 & North America & $\mathrm{N}$ \\
\hline Environmental Defense Fund & 22 & North America & $\mathrm{N}$ \\
\hline Catholic Relief Services & 19 & North America & $\mathrm{N}$ \\
\hline $\begin{array}{l}\text { Campagna per la riforma della } \\
\text { Banca mondiale }\end{array}$ & 19 & Western Europe \& Australia & $\mathrm{N}$ \\
\hline Debt and Development Coalition & 19 & Western Europe \& Australia & $\mathrm{N}$ \\
\hline Social Justice Committee & 16 & North America & $\mathrm{N}$ \\
\hline World Economy, Ecology and Development & 16 & Western Europe \& Australia & $\mathrm{N}$ \\
\hline Central and Eastern European Bankwatch & 14 & Western Europe \& Australia & $\mathrm{N}$ \\
\hline Shining Stone Community Action & 14 & East Asia & $\mathrm{S}$ \\
\hline Global Health Council & 13 & North America & $\mathrm{N}$ \\
\hline Institute for Policy Studies & 13 & North America & $\mathrm{N}$ \\
\hline World Conservation Union - IUCN & 13 & Western Europe \& Australia & $\mathrm{N}$ \\
\hline Third World Network & 13 & East Asia & $\mathrm{S}$ \\
\hline World Wildlife Fund & 12 & North America & $\mathrm{N}$ \\
\hline
\end{tabular}


Chart 2b: Top NGO Performers, by Attendance Intensity, IMF

\begin{tabular}{|c|c|c|c|}
\hline NGO & $\begin{array}{c}\# \text { of } \\
\text { Attendees }\end{array}$ & Regions & $\begin{array}{l}\text { Macro- } \\
\text { Region }\end{array}$ \\
\hline Jubilee 2000 Network & 75 & North America & $\mathrm{N}$ \\
\hline Oxfam International & 73 & North America & $\mathrm{N}$ \\
\hline World Vision & 49 & North America & $\mathrm{N}$ \\
\hline Friends of the Earth & 45 & North America & $\mathrm{N}$ \\
\hline Action Aid & 33 & North America & $\mathrm{N}$ \\
\hline $\begin{array}{l}\text { European Network on Debt and } \\
\text { Development (EURODAD) }\end{array}$ & 28 & Western Europe \& Australia & $\mathrm{N}$ \\
\hline Save the Children & 28 & North America & $\mathrm{N}$ \\
\hline Bank Information Center & 27 & North America & $\mathrm{N}$ \\
\hline Bretton Woods Project & 25 & Western Europe \& Australia & $\mathrm{N}$ \\
\hline Center of Concern & 22 & North America & $\mathrm{N}$ \\
\hline Christian Aid & 20 & Western Europe \& Australia & $\mathrm{N}$ \\
\hline Debt and Development Coalition & 20 & Western Europe \& Australia & $\mathrm{N}$ \\
\hline Social Justice Committee & 18 & North America & $\mathrm{N}$ \\
\hline Trocaire & 18 & Western Europe \& Australia & $\mathrm{N}$ \\
\hline InterAction & 16 & North America & $\mathrm{N}$ \\
\hline $\begin{array}{l}\text { Campagna per la riforma della } \\
\text { Banca mondiale }\end{array}$ & 15 & Western Europe \& Australia & $\mathrm{N}$ \\
\hline Wateraid & 14 & Western Europe \& Australia & $\mathrm{N}$ \\
\hline World Economy, Ecology and Development & 14 & Western Europe \& Australia & $\mathrm{N}$ \\
\hline $\begin{array}{l}\text { African Forum and Network on Debt and } \\
\text { Development (AFRODAD) }\end{array}$ & 13 & Africa & $\mathrm{S}$ \\
\hline New Rules for Global Finance Coalition & 12 & North America & $\mathrm{N}$ \\
\hline $\begin{array}{l}\text { Norwegian Campaign for the Cancellation } \\
\text { of Third World Debt (SLUG) }\end{array}$ & 12 & Western Europe \& Australia & $\mathrm{N}$ \\
\hline $\begin{array}{l}\text { Cooperation International pour la } \\
\text { Developpement et la Solidarite (CIDSE) }\end{array}$ & 11 & Western Europe \& Australia & $\mathrm{N}$ \\
\hline $\begin{array}{l}\text { Catholic Fund for Overseas Development } \\
\text { (CAFOD) }\end{array}$ & 10 & Western Europe \& Australia & $\mathrm{N}$ \\
\hline Catholic Relief Services & 10 & North America & $\mathrm{N}$ \\
\hline Central and Eastern European Bankwatch & 10 & Western Europe \& Australia & $\mathrm{N}$ \\
\hline
\end{tabular}

The data also reveals the poorest performers. 160 NGOs at the Bank and 150 at the Fund only sent one person to one meeting over the entire period. Another 35 (Bank) and 45 (Fund) only attended one meeting, albeit with more than one staffer. Therefore, at the Bank, of 358 NGOs attendant across the entire seven year frame, 54\% (195) have only attended one of $82+$ CSDs. (98 of these one-timers are from the North; 97 are from the South.) At the Fund, of the 287 total attendant NGOs, 76\% (195) have only attended 
one of the 47+ CSDs (95 from the North, and 100 from the South). Two trends emerge - a skew toward Northern NGO attendance, and NGO disinterest in Fund CSDs.

\section{From Where $\cdots$}

The following frequency distributions reinforce the skew toward Northern NGOs and the Bank. Graphs 1 and 2 reveals regional origin cross-referenced against topical interest. ${ }^{43)}$ Graph 3 lists NGO attendance longitudinally by macro-region.

\section{Graph 1}

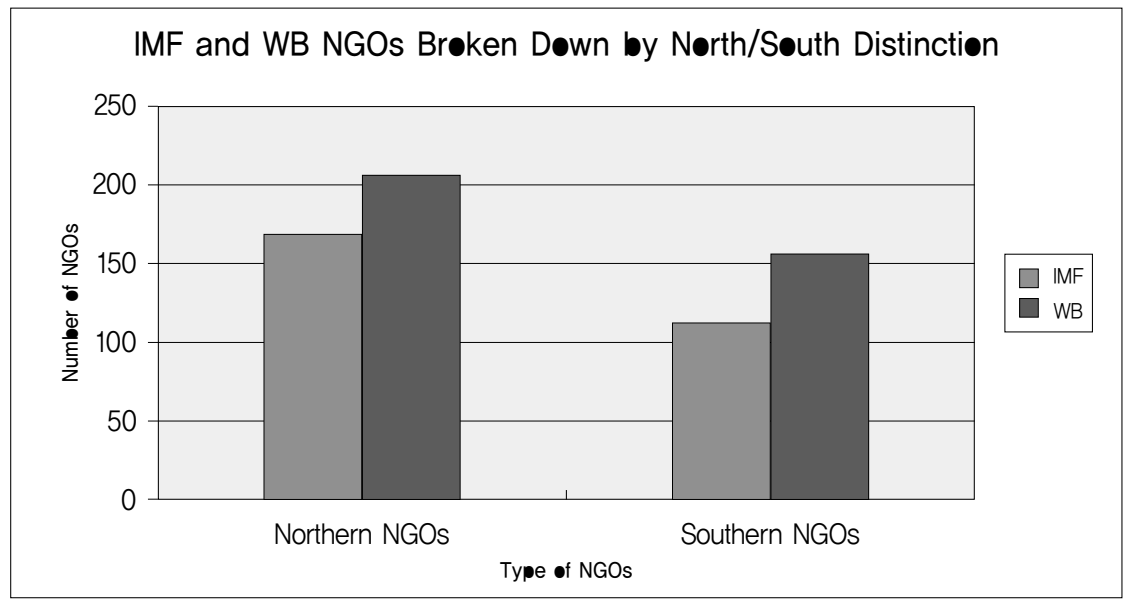

Graph 2a

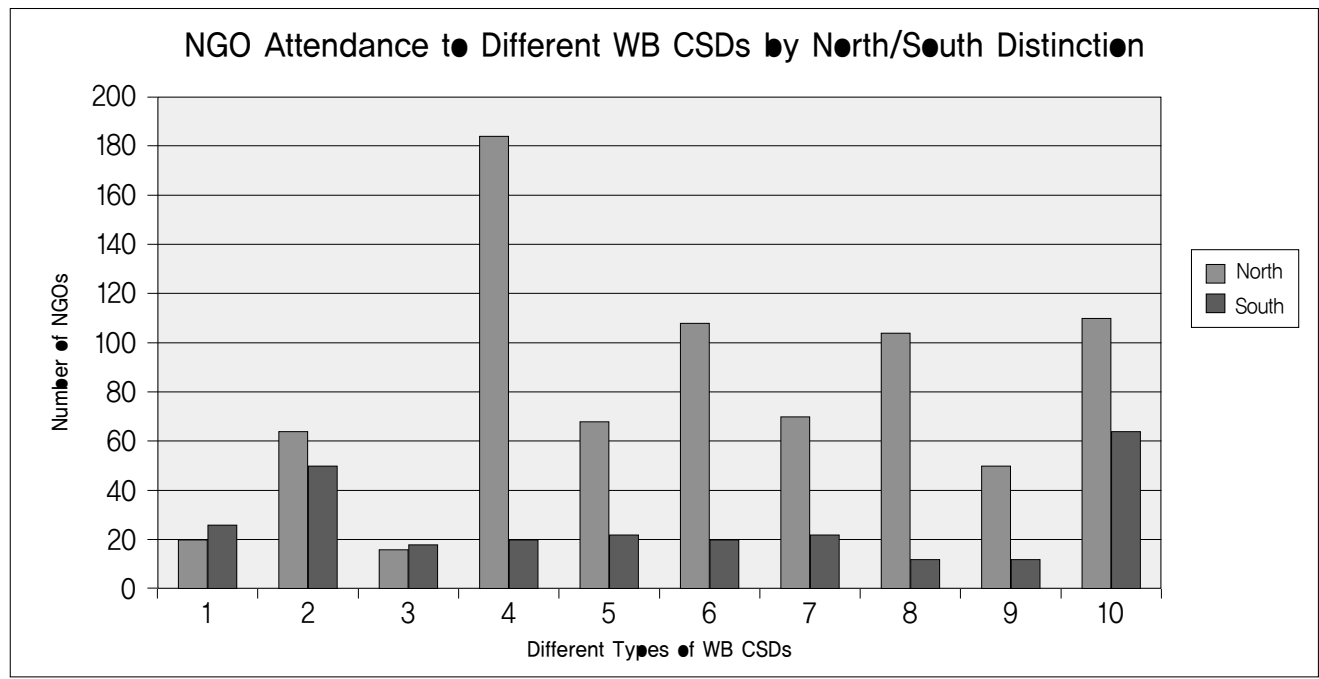

Legend (Graph 4 also): 1) individual countries and regions, 2) globalization/development policy, 3) development financing and the private sector, 4) aid and debt, 5) health, 6) poverty, 7) environment/energy/infrastructure/industry, 8) rules governing IFI instruments, 9) trade, and 10) transparency/oversight/accountability/BWI governance. 


\section{Graph 2b}

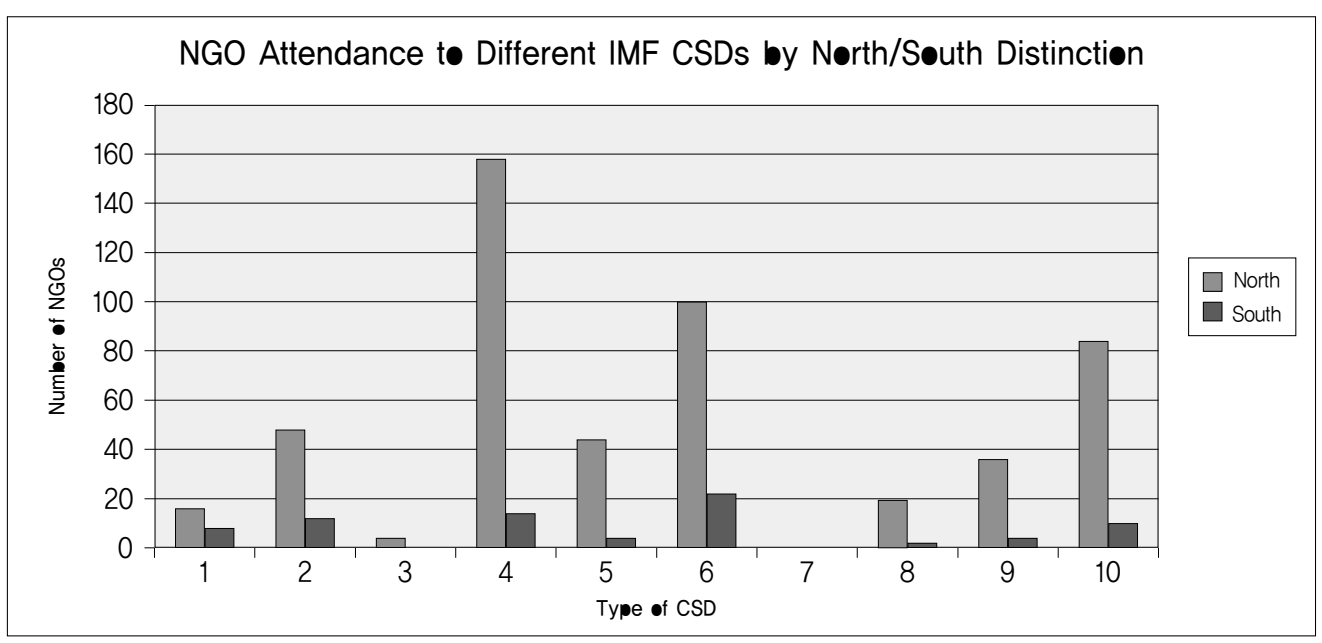

Graph 3

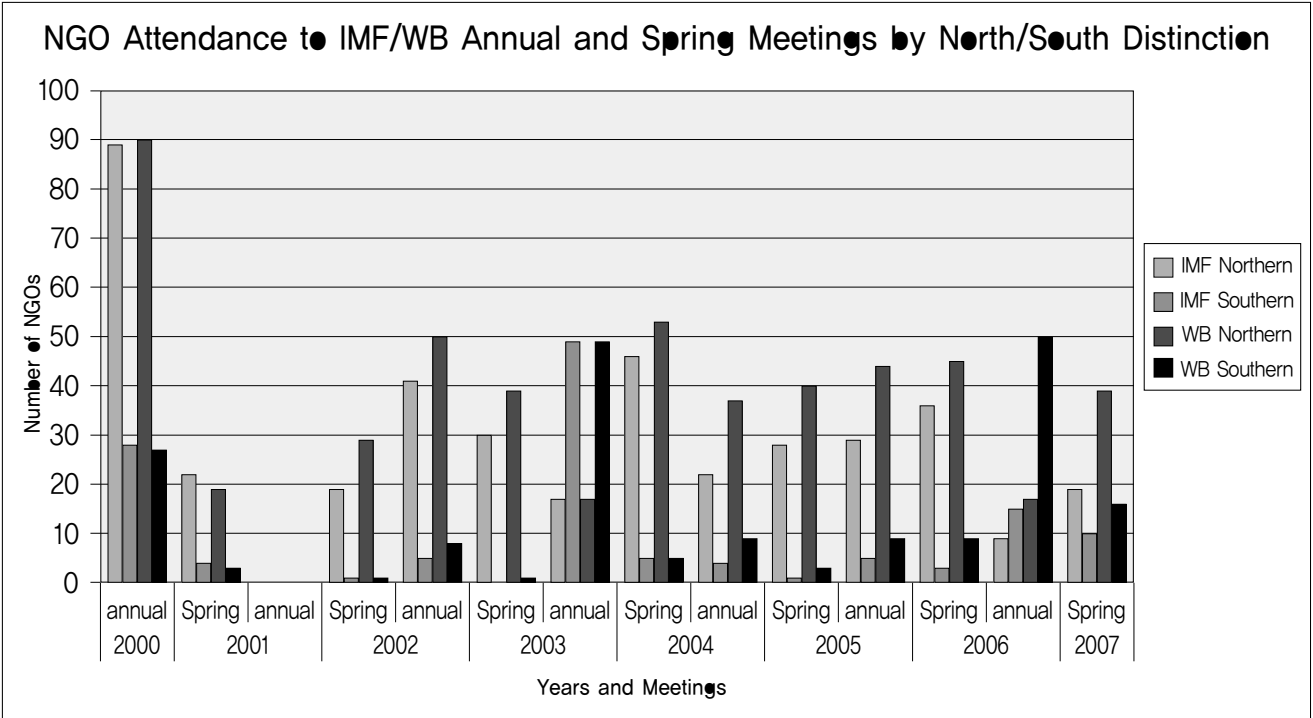

Regardless of the manipulation of the data behind these histograms, they are revealing. Northern NGOs have consistently out-attended Southern ones several times over, and NGO interest in the Bank is noticeably higher.

43) Other histograms, such as attendance by year, are available. Please contact me directly at rekelly@ pusan.ac.kr. 


\section{To What Kinds of Meetings?}

The following data break-down the CSDs by the 10 topical categories mentioned above. Graph 4 provides the number of meetings by type.

Graph 4

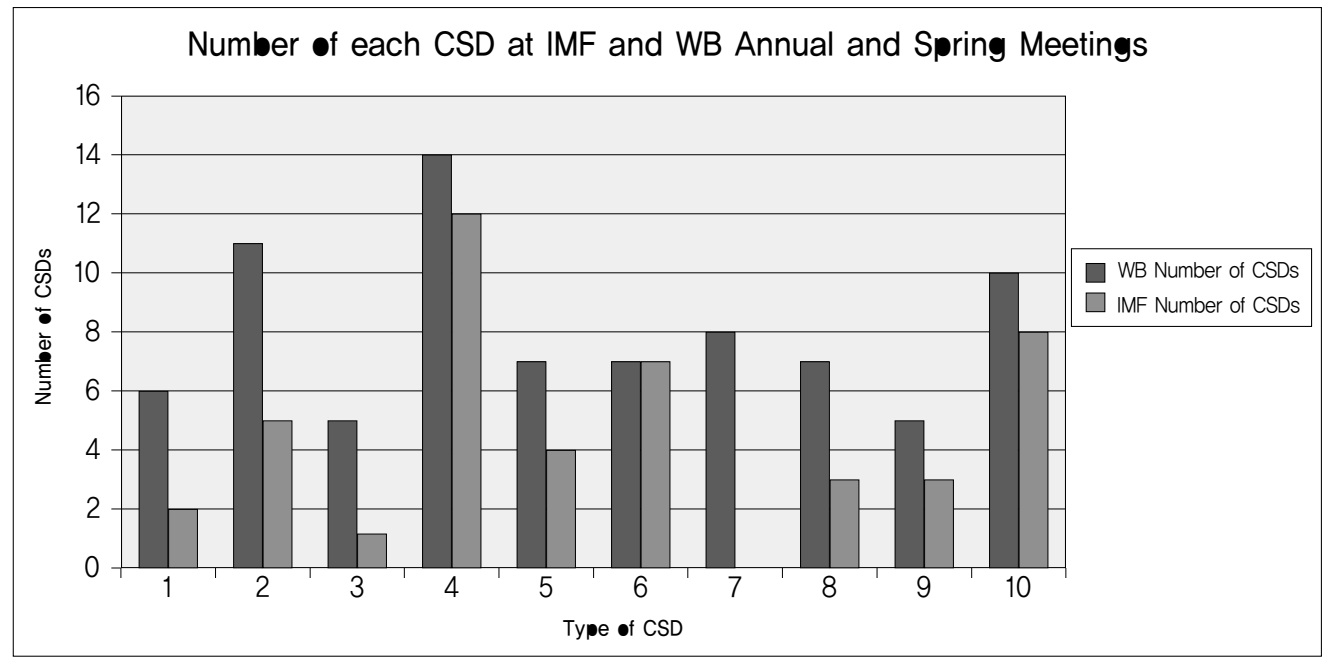

The dominant issue, defined by meeting frequency, is clearly aid and debt (4), followed by the internal governance of the BWI themselves (10), globalization's rules (2), and health (6). Graph 2 suggested very high Northern interest in debt, nearly an order of magnitude greater than very meager Southern interest. Yet on the next three issues, Southern interest is high compared to the remaining issues. The inordinate primacy of the aid/debt issues reflects the concerns of the Northern leftist NGOs that dominate GCS at the BWI. But the flatter distribution on the other key issues also suggests that Southern colleagues can set the agenda in turn, and that North-South NGO coalitions are a possibility. The data also reveal significantly more Bank than Fund meetings. This reflects the greater general interest in the Bank.

\section{Aggregate Portrait}

To conclude, graphs 5 and 6 provide an aggregate longitudinal portrait of NGO attendance at the CSDs. Graph 5 documents the number of attendant NGOs, and 6 the number of attendant NGO staff. Trendlines are included. They reveal a general decline in attendance, but for the slight rise of NGO staff attending Bank functions. The decline 
at the Fund, on both charts, is quite precipitous, foreshadowed by earlier data that $54 \%$ of Bank NGOs and 76\% of Fund NGOs have attended only one meeting. Interest from NGOs in the CSDs is clearly waning at the Fund, and slightly at the Bank.

\section{Graph 5}

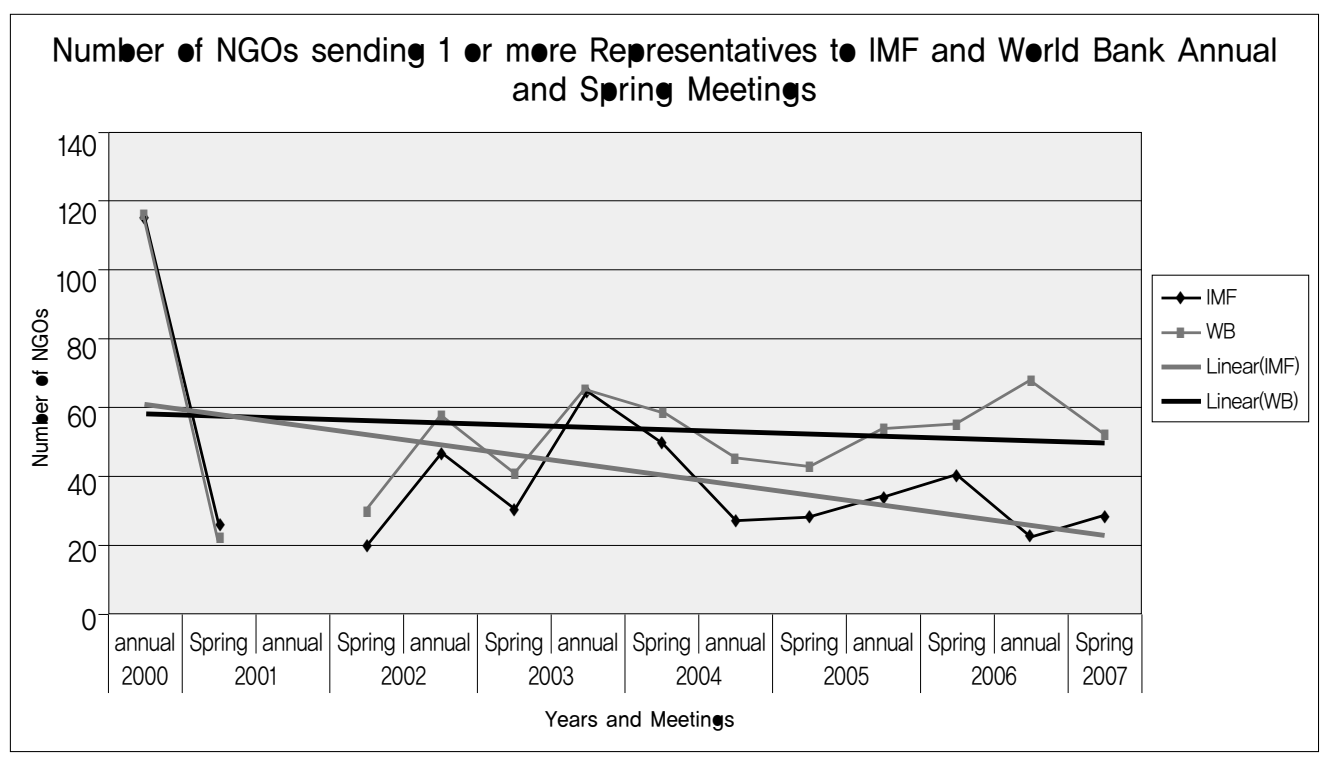

Graph 6

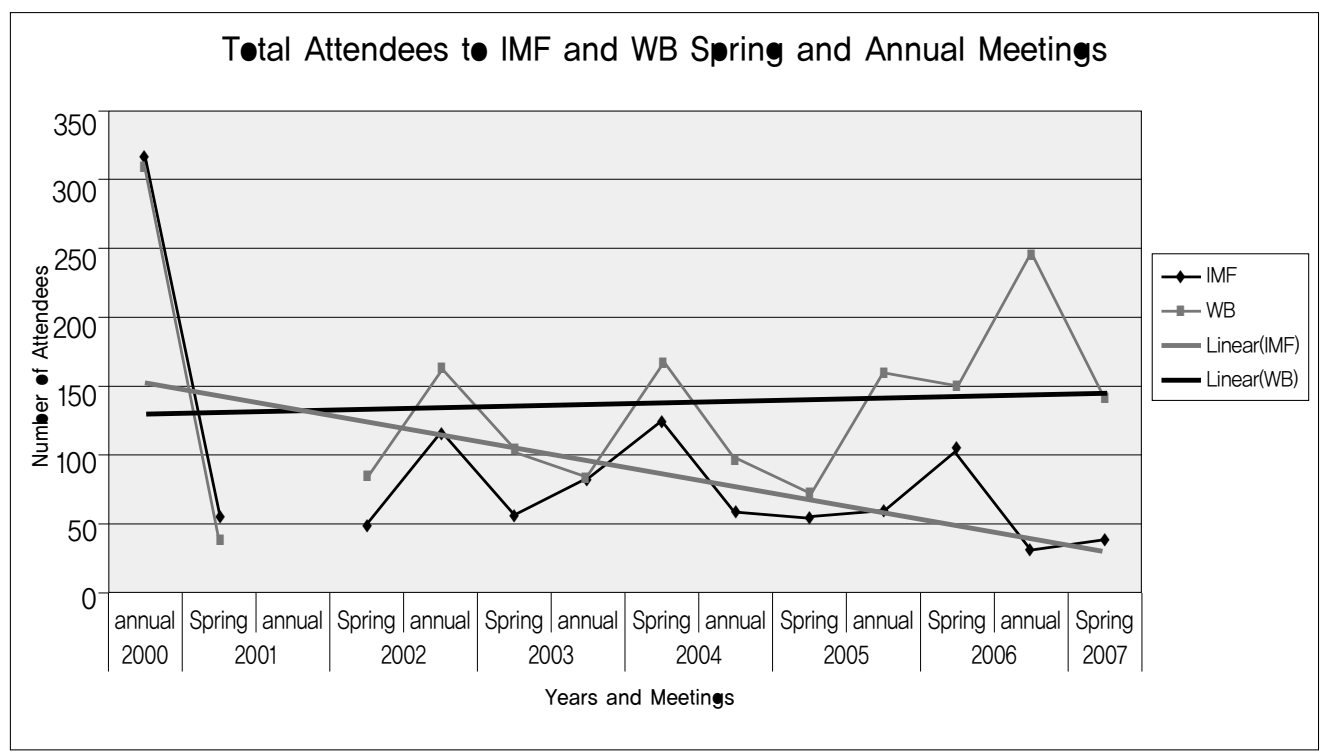




\section{Global Governance at the BWI}

Inductive inference from this data reveals a narrative of NGO engagement at the BWI that is in general decline, dominated by Northern NGOs - but with some topical openness to Southern concerns - and characterized by a growing breach between the Bank and Fund's engagement with NGOs. Theoretically, the data suggest that the NGOs around the BWI increasingly form an epistemic community, albeit coopted by the bureaucratization of the CSD process.

\section{Decline}

A noticeable secular decline in CSD attendance (graphs 5 and 6) continues the earlier story of BWI-NGO interaction. NGOs sensed a weakening of the BWI after the MAI and Seattle. A possibility of serious change was in the air. This motivated very high attendance at the first 2000 Prague meetings. For the BWI, discussions were a small price to relieve their troubled reputation in Western publics; talk is cheap. Hence, from the start, there were wildly differing expectations from the dialogues, as seen in the acrimonious contention over joint reviews like the Structural Adjustment Policy Review Initiative or the Extractive Industries Review. ${ }^{44)}$

The Bank and Fund have not actually moved much in response to NGO pressure. (Some policy shifts can be partially attributed to NGOs [debt relief and the environment particularly.$^{45}$ ) Particularly the Fund has entertained NGO engagement generally as a defensive exercise designed to "inform," if not co-opt, NGO critics. ${ }^{46)}$ Scholte finds "management exchanges with civil society have had more of a public relations character;" central Fund premises were never under real threat. ${ }^{47)}$ At the Bank too, NGOs failed to make great inroads. To the Fund's credit, it has honestly expressed its skepticism of NGO engagement, ${ }^{48)}$ but the Bank raised expectations through its open

44) Interviews with the Bank, Fund and NGO community, June-July, 2004, confirmed this gap in perception. One Bank official with responsibility for NGO outreach said part of his job was "expectation management."

45) Robert Wade. "Greening the Bank: The Struggle over the Environment, 1970-1995," in Devesh Kapur, John Lewis and Richard Webb, eds., The World Bank: Its First Half Century, Volume II: Perspectives (Washington, DC: Brookings, 1997): 611-734; Scholte, "Civil Society and IMF," p.33.

46) IMF, Annual Reports (Washington: IMF): 1997: 198; 1998: 71, 72-73, 155; 2000: 154.

47) "Civil Society and IMF," 20; Ngaire Woods, The Globalizers (Ithaca, NY: Cornell UP), 2006: 200-04; Scholte, "Civil Society and IMF," 20.

48) Thomas Dawson and Gita Bhatt, "IMF and Civil Society Organizations: Striking a Balance," IMF Policy Discussion Paper 01/2 (2001). 
political opportunity structure and significant official interaction with NGOs on projects especially. ${ }^{49)}$ But the Bank inevitably disappointed NGOs. The IMF sets the macrolending paradigm within which the Bank moves, and Bank internal evaluations have found mixed opinions on NGO engagement as well as its value. ${ }^{50)}$ In an institution

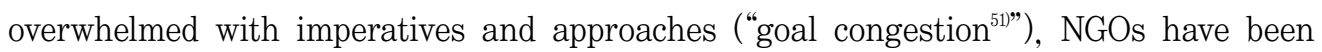
reduced to the position of one more interest group clamoring to be heard. ${ }^{52)}$

The eventual disappointment of these poor results has depressed the turnout numbers. The heady talk of humanized globalization of the NGOs' golden days (between Seattle in December 1999 and the 9/11 attacks) never materialized. As policy change flagged, expectations dropped, and with it attendance. Indeed, the security crackdown on street protesting since 9/11 makes this downturn more significant. 9/11 closed the extrainstitutional option which NGOs were cultivating at the BWI since the 1980s. This closure should have driven them toward the CSDs as a last avenue of pressure - a likely significant bump in attendance if the NGOs had a choice of either attendance or no action at all. Yet more than 50\% of the NGOs who have come to a CSD, never returned. If deep policy shifts were to be had from the CSD process, attendance should fluctuate more and rise somewhat. It has not. ${ }^{53)}$

All that remains is a hard core of repeat, mostly Washington-based and Western European activists (Charts 1 and 2). A generous interpretation suggests they are fighting the good fight. A harsher one, with strong support from interview data with BWI staff, is that these are professionalized NGO opponents who need to attend and engage as their raison d' etre. Unless the annual meetings are held outside the US, Southern groups are regularly underrepresented by an order of magnitude. The CSDs are settling into an elite, bureaucratic discourse that has alienated most NGO participants. Jan Scholte, a friend of NGO/GCS pressure on IOs, notes the low "rotation of civil society actors who enter dialogue with GG agencies" and worries about a "tired

49) World Bank "Annual Progress Report on World Bank-NGO Cooperation," (Washington: WB, 1988-2007); World Bank, "Issues and Options for Improving Engagement Between the World Bank and Civil Society Organizations," (Washington: WB, 2005).

50) Saad Eddin Ibrahim, "Nurturing Civil Society at the World Bank: An Assessment of Staff Attitudes Toward Civil Society" (Washington: WB, 1998); World Bank, "Nongovernmental Organizations in World Bank-Supported Projects" (Washington: WB, 1999).

51) Christopher Gilbert, Andrew Powell and David Vines, "Positioning the World Bank," in, Gilbert and Vines, eds. World Bank: Policies and Structures (NY: Cambridge UP, 2000): 39-86.

52) Woods, Globalizers, 200-04.

53) On utility of a counterfactual logic to the study of NGOs and IOs, see Scholte, "Civil Society and IMF," 26. I would like to thank my research assistant, Prakash Vemulapalli for the argument of this paragraph. 
civil society establishment [that] may counterproductively obstruct the entry of energetic newcomers who could reinvigorate moral sensibilities. ${ }^{54)}$ " While possibly a TAN, this is better described as a co-opted, epistemic community. ${ }^{55)}$

\section{Northern Domination?}

A common observation on NGO participation in GG is the domination of Northern groups; this data-set bears that out. Charts 1 and 2 and graphs 1 and 2 particularly reveal a striking attendance imbalance. The sheer volume of Northern attendance is comparatively enormous. But that picture is incomplete. Graph 3 suggests that the gap is closing, particularly when the annual meetings are held in the South. The 2003 Abu Dubai and 2006 Singapore meetings display clear spikes in attendance; Southern attendance was greater than Northern at both.

Further, Northern domination of attendance does not translate into narrowly Northern issue coverage. The platykurtic distribution of meeting types (Graph 4) does not mirror clustered Northern attendance patterns (Graph 2). Clearly the dominant issue to Northern groups is debt relief, and Southern interest in that is comparatively low (Graph 2 ). Beyond this, the South does bring its central issues (defined by attendance on Graph 2) to the table-specifically globalization policy, transparency and health. These have the highest number of meetings after the debt issue (graph 4).

This mixed portrait suggests that Northern dominance may be more a factor of geography than Southern disinterest or Northern zeal. Meetings in the South enjoyed strong Southern attendance. Further, the broad distribution of meeting types suggest increasing North-South coalition building-defined by a shared agenda and common causes. Deeper North-South interweaving and coalitions bolsters notions of GCS as a truly global space with global actors (such as TANs or TSMOs), rather than nationally or regionally fragmented pieces occasionally interacting. ${ }^{56)}$

\section{Breach with the Fund}

Disaggregation of the secular downward trend in attendance reveals that NGOs are

54) “Civil Society and Legitimation," 24, 25.

55) Robert Kelly, "Micro-View of Global Governance: Spring and Annual Meetings of the Bretton Woods Institutions," Transnational Associations, 2003/4: 203-206; Asunción St. Clair, "World Bank as a Transnational Expertised Institution," Global Governance 12/2 (2006): 55-75.

56) Wapner, "Governance;" Keck and Sikkink, Activists; Smith, Chatfield, and Pagnucco, Transnational Social Movements;" Sidney Tarrow, Power in Movement (NY: Cambridge UP, 1998): ch. 11. 
giving up on engagement with the Fund, increasingly focusing their, albeit declining, interest on the Bank. ${ }^{57)}$ Scholte has remarked the civil society engagement with the Fund is still "in the foothills" after several decades. ${ }^{58)}$ Graphs 3, 5 and 6 repeatedly reveal the mostly striking statistical find of the report-a marked decline in NGO interest in Fund CSDs, and steady, low Southern participation. Either the IMF has lost relevance to the global NGO community, or the global NGO movement has found the IMF to be unwilling to change. ${ }^{59)}$ In either case, the data shows decreasing attendance and intensity and raises serious questions about the success of the meetings. By contrast, attendance decline at the Bank is slight and may be reversed in the future.

A closer look at the data (graphs 5 and 6) reveals that the IMF 2006 Annual (in Singapore) failed to achieve the Southern NGO attendance that characterized the Bank 2003/2006 Annual and the 2003 IMF Annual. This lack of attendance and participation in the face of increasing Southern NGO participation at the Bank suggests a lack of trust in IMF by the NGO community. This is consistent with my earlier finding that the IMF engages NGOs primarily for institutional defense. ${ }^{60)}$ NGOs represent a pernicious environmental influence to which the Fund must adapt. By contrast the Bank has flirted with NGOs as useful tools in its mission completion. These contrasting attitudes of resistance and utility correlate comfortably with the relevant attendance data.

The Fund is more closely tied to the neoliberal IFA against which the NGOs are set than the Bank. The Bank can raise its own resources; the Fund cannot, and this reduces its wiggle room for creativity. It is smaller in staff and resources than the Bank, which can more easily afford the personnel and fiscal burden of NGO outreach inefficiencies. Finally, the Fund is more on-message and clearer in its mission than the Bank. ${ }^{61)}$ The Fund has watched the Bank has sink into "goal congestion" and disarray. ${ }^{62)}$ Ngaire Woods has noted that it has struggled to maintain a few core tasks with clearly delimited lines of authority. Holding this line has included resisting NGO penetration. ${ }^{63)}$ In the words of one NGO interviewee, "we just don't get much from the Fund, so we go to the Bank." ${ }^{64)}$

57) Earlier (Kelly, "Impact"), I found the beginnings of this split, but it is accelerating quite rapidly.

58) "Civil Society and IMF," 23.

59) One NGO staffer, who has worked on these issues for many years, remarked to me in passing in 2005, "the IMF simply does not change."

60) Kelly, "Impact."

61) Celine Tan, "Reform or Reinvent? The IMF at a Crossroads," Global Governance 12/4 (2006): 511.

62) Jonathan Pincus and Jeffrey Winters, eds. Reinventing the World Bank (Ithaca: Cornell UP, 2002); IMF interviewees, June-July 2004.

63) The Globalizers, 6-9, 40-43, 186-88. 


\section{Theory: A Coopted Epistemic Community}

Theoretically, the data reveals a congealing transnational, coopted epistemic community of routinely interacting BWI and NGO officials, including some meaningful cross-border NGO coalitions. This bolsters GG contentions ${ }^{65)}$ that, a) GCS is a meaningful layer of global sociality with a policy-relevant wing, and b) that TANs and TSMOs are taking shape, although not nearly with the clarity and regional equality those terms suggest. But the declining participation in the CSD process suggests the organizational downside of GG - foreshadowed by the contemporary irrelevance of ECOSOC: NGO marginalization into a coopted, bureaucratized, hermeneutic circle with a few regular BWI interlocutors and little policy impact. ${ }^{66)}$

The community of social change NGOs around the Bank and Fund is comparatively large. Sikkink and Smith identified around 1000 such groups through the UIA dataset. The combined Bank/Fund attendance list is close to 400. So GCS at the BWI is a substantial phenomenon worthy of the name. But Charts 1 and 2 also demonstrate how quickly attendance drops off. At the Bank, of 358 attendant NGOs, only 20 have attended more than ten meetings out of the 82+ total. At the Fund, only 18 have attended more than ten of $47+$. Referenced against the headquarters' locations, the top performing NGOs over time are a fairly constant clique of mostly Western European and Washington-based NGOs.

Further, participant observation at five CSD blocs (spring: 2004, 05, and 06; annual: 2004 and 05) suggests that the attendant staff from the BWI and NGOs are frequently the same. (This cannot be formally demonstrated, because individual names have been redacted from the data-set for anonymity purposes.) Interviewees from the BWI and NGO community (in 2004) also noted the circulation of the same people discussing the same issues again and again; Scholte too has noted this in his concern for greater "rotation." This suggests that NGO engagement is increasingly professionalized and routinized in a multi-stakeholder process. An epistemic community of individuals wellknown to each other, sharing similar training and interests, and meeting regularly has evolved. ${ }^{67)}$ Professionalization is widely seen as desirable to improve the quality of NGO

64) Anonymous personal conversation at Spring 2005 CSDs. I am indebted to my research assistant, Prakash Vemulapalli, for helpful inputs on this section.

65) Keck and Sikkink, Activists; Wapner, "Governance;" Jan Scholte, Globalization (London: Palgrave, 2005).

66) St. Clair, "World," p.86; Jo Marie Griesgraber and Oscar Ugarteche, "The IMF Today and Tomorrow: Some Civil Society Perspectives," Global Governance 12/4 (2006): 351-59; Scholte, "Civil Society and Legitimation" and "Civil Society and IMF." 
input, but it simultaneously threatens the spirit of NGO engagement. ${ }^{68)}$

For the flip-side of this professionalization is NGO marginalization. The street protest option is closed, and CSD consultation is contracting toward a predictable series of parties rehearsing familiar disputes with only limited impact on the policy process actually occurring at the concurrent Spring and Annual Meetings. The current financial crisis, e.g., is being addressed in the BWI without substantial NGO input. The CSDs constitute a hermeneutic circle, resulting in growing consultation-fatigue on both sides. Rigidity and bureaucratic staleness threaten, and indeed, they undid two previous attempts by the World Bank to consult NGOs regularly. The World Bank-NGO Committee of the 1980s and 90s imploded under bureaucratic inertia and irrelevance, and its successor, the still-born Joint Facilitation Committee collapsed amid acrimony and infighting on the NGO side. ${ }^{69)}$ Scholte's fear that "civil society offers veritable legitimation at the GG table not by cooptatively warming up the seats, but by counterhegemonically heating up the proceedings" is coming to pass. ${ }^{70)}$

This may be impossible dilemma for NGOs. Many have noted that NGOs need internal institutional allies to succeed. ${ }^{71)}$ In reaching into the organizations to promote change, NGOs must inevitably professionalize. Busy BWI officials will simply no longer meet with young unprepared staff or interns, and the NGOs of charts 1 and 2 have increasingly meet this demand for serious product and preparation. The work of NGOs such as the Bank Information Center, Eurodad, or World Vision is respected in the institutions. Such NGOs form an epistemic community with interested BWI staff, as they share the language and academic skills relevant to 'compete' in the institutional policy process. Participant observation of the CSD found a high level of professional, particularly economic, expertise from most participants.

Unsurprisingly this drives away other, smaller, less well-trained or resourced groups, and the data show it. The participation of non-Northern, non-expertised NGOs drops away dramatically. The remaining NGOs will increasingly resemble lobbies or interest groups, or in the language of GG theory - a coopted epistemic community.

Many NGO campaigners fear this outcome, because of the cultural distance it places

67) Kelly, "Micro-View."

68) Donini, "Bureaucracy;" Scholte, "Civil Society and IMF," 31-32.

69) Paul Nelson, World Bank and Non-Governmental Organizations (NY: St. Martin's Press, 1995); http://web.worldbank.org/WBSITE/EXTERNAL/TOPICS/CSO/0,, contentMDK:20133856 pagePK:220503 piPK:220476 theSitePK:228717,00.html.

70) Scholte, "Civil Society and Legitimation," 25.

71) Jonathan Fox and David Brown, "Introduction," in Fox and Brown The Struggle for Accountability (Boston: MIT Press, 1998), 4; Woods, Globalizers; Scholte, "Civil Society and IMF," 37. 
between the lively grassroots of GCS and the requisite formalism of interaction in the halls of the BWI. Scholte says that "many subordinated circles *.find the NGO form to be culturally alien $\cdots$ these constituencies frequently prefer social movement modes of action. ${ }^{72) " ~ B u t ~ c l e a r l y ~ r a u c o u s ~ s o c i a l ~ m o v e m e n t ~ a c t i o n ~ c a n n o t ~ s u b s t i t u t e ~ f o r ~ t h e ~ a n a l y s i s ~}$ BWI interlocutors demand from NGOs. Worse, if NGOs' roots in the protest and grassroots communities diminish, their ability to leverage an external or street threat declines. This creates space for IOs to ignore them. Scholte worries that "official circles expect 'consultation' of civil society to give a veneer of public endorsement to policy that has in effect already been decided. ${ }^{73}$ " If the long-term cost of professionalization is loss of 'NGO spirit,' the medium-term cost is IO willingness to slight NGOs with attenuated grassroots.

The cost/benefit ratio to NGOs of institutional access versus marginalization is not clear. As access increases, so does marginalization. This awkward catch-22 will bedevil North-South NGO interaction so long as dramatic coalitional inequities in wealth and education persist. It will reinforce Northern dominance of coalitions and continually threaten the cooptation of NGO interlocutors into bureaucratized epistemic communities.

\section{Future of CSDs}

The data set presented here is a work in progress. Every six months it is updated as new attendance information is compiled. The secular downward trend at the Fund looks fairly predictable by now, but the future trend at the Bank is unclear. Bank CSDs may benefit from a migration of NGOs out of Fund CSDs, but in the long-run NGOs will likely abandon this process, as they have others before it, if no policy results emanate.

The future of the CSDs, as an institutional embodiment of routinized GG, is unclear. The regular interaction with the most professionalized and Northern NGOs has reduced the rambunctious, unpredictable quality many find most appealing in NGO/GCS input As NGOs have acquired internal institutional allies to push more successfully for their causes, the pressures for conformity and bureaucratic proceduralism have risen. 'Freespirited' NGOs resent this organizational bureaucratization of GG into 'epistemic communities,' 'TANs,' and other such academic jargon. In NGO terms, consultationfatigue with stodgy IOs corrupts the democratic, participative, free-wheeling GCS embodied by the World Social Fora. Similarly, the IFIs, particularly the Fund, resent the

72) "Civil Society and Legitimation," 24.

73) "Civil Society and Legitimation," 21. 
diffusion of authority a 'multi-stakeholder' process suggests. To professional IO staff, NGOs legitimacy claims are highly questionable; most are quite oligarchic, undemocratic, and opaque. As Scholte notes, IO officials prefer a "restricted circle of well-known $\cdots$ and high-profile NGOs. ${ }^{74)}$ And expansive consultation with GCS drives up transaction costs on programming with unclear benefits.

In such a contentious environment, an important future question for research is, why would NGOs still come to CSDs. The likely answer is prestige. CSD attendance is a mark of legitimacy for NGOs. In the North, perceptions that they are 'players' in the GG process insures continued funding and social prestige in policy-making circles. In the South, BWI interest insures against government repression and lifts social prestige in societies profoundly isolated from the global economy. Further interview work, focused on the top performers of Charts 1 and 2, will elucidate this question. A second question for future investigation is the continuing trade-off between access and bureaucratization NGOs face. Field work in this area, both formal and informal interviews and interactions with NGOs, has made clear the agonizing dilemma Northern NGOs perceive. No regular answer was forthcoming. The data suggests the trade-off is serious; it is as yet unresearched.

This dataset mapped just one portion of GCS. It provides a structured portrait of regular interaction between two major actors in GG-social change NGOs and IOs. Insofar as GG theory searches for routines and patterns that indicate the emergence of global policy processes ${ }^{75)}$ the dataset reveals established (albeit declining) patterns with some predictability. Obviously states and MNCs are missing, but the quantitative data gaps are most severe in the study of GCS. This dataset builds on those of ECOSOC, UIA, and Sikkink and Smith, and may be a model for future, more fine-grained data-collection.

74) Scholte, "Civil Society and Legitimation," 29.

75) Ougaard and Higgott, Towards; Wilkinson and Hughes, Global Governance; UN Commission, Common Future. 


\section{REFERENCES}

Albrow, Martin and Helmut Anheier, "Violence and the Possibility of Global Civility," in: Anheier, Mary Kaldor, and Marlies Glasius, eds. Global Civil Society 2006/7 (London: Sage): 1-17.

Anderson, Kenneth and David Rieff, "Global Civil Society: A Skeptical View," in: Marlies Glasius, Mary Kaldor and Helmut Anheier, eds. Global Civil Society 2004/5 (London: Sage): 26-39.

Anheier, Helmut and Hagai Katz, "Mapping Global Civil Society," in Marlies Glasius, Mary Kaldor and Anheier, eds., Global Civil Society 2003 (London: Sage): 241-258.

Bhagwati, Jagdish, In Defense of Globalization (Oxford: Oxford UP, 2005).

Coleman, William and Sarah Wayland, "Origins of Global Civil Society and Nonterritorial Governance," Global Governance, 12/3 (2006): 241-61.

Commission on Global Governance, Our Global Neighborhood (Oxford: Oxford UP, 1995).

Dawson, Thomas, and Gita Bhatt, "IMF and Civil Society Organizations: Striking a Balance," International Monetary Fund Policy Discussion Paper 01/2 (Washington: IMF, 2001).

Donini, Antonio, "Bureaucracy and the Free Spirits: Stagnation and the Innovation in the Relationship Between the UN and NGOs," in Thomas Weiss and Leon Gordenker, eds., NGOs, the UN and Global Governance (Boulder: Lynne Rienner, 1996): 83-101.

Florini, Ann, ed., Third Force: The Rise of Transnational Civil Society (Washington: Carnegie Endowment, 2000).

Fox, Jonathan and David Brown, "Introduction," in Fox and Brown The Struggle for Accountability (Boston: MIT Press, 1998): 1-47.

Gilbert, Christopher, Andrew Powell and David Vines, "Positioning the World Bank," in, Gilbert and Vines, eds. World Bank: Policies and Structures (NY: Cambridge UP, 2000): 39-86.

Gilpin, Robert, Global Political Economy (Princeton: Princeton UP, 2001).

Griesgraber, Jo Martie and Oscar Ugarteche, "The IMF Today and Tomorrow: Some Civil Society Perspectives," Global Governance 12/4 (2006): 351-59.

Ibrahim, Saad Eddin, "Nurturing Civil Society at the World Bank: An Assessment of Staff Attitudes Toward Civil Society" (Washington: WB, 1998). 
International Monetary Fund, Annual Report (Washington: IMF, 1997, 1998, 2000).

Kaldor, Mary, Helmut Anheier, and Marlies Glasius, "Global Civil Society in an Era of Regressive Globalization,” in: Glasius, Kaldor and Anheier, eds., Global Civil Society 2003 (London: Sage): 3-33.

Karns, Margaret and Karen Mingst, International Organizations (Boulder: Lynne Rienner, 2004).

Keck, Margaret and Kathryn Sikkink, Activists Beyond Borders (Ithaca: Cornell UP, 1998).

Kelly, Robert, "Micro-View of Global Governance: Spring and Annual Meetings of the Bretton Woods Institutions," Transnational Associations, 2003/4: 203-206.

Kelly, Robert, "Impact of NGOs on the Bretton Woods Institutions-Executive Summary," (Washington: World Bank, 2006), available at http://web. worldbank. org/WBSITE/EXTERNAL/TOPICS/CSO/0, contentMDK: 20127029 menuPK:277368 pagePK:220503 piPK:220476 theSitePK:228717, 00.html.

Kelly, Robert, "From IR to Global Governance Theory," Journal of Civil Society, 3/1 (2007): 81-99.

Keohane, Robert and Joseph Nye, eds. Transnational Relations and World Politics (Cambridge: Harvard UP, 1971).

Khagram, Sanjeev, James Riker, and Kathryn Sikkink, "From Santiago to Seattle: Transnational Advocacy Groups Restructuring World Politics," in, Sanjeev Khagram, James Riker, and Sikkink, eds,. Restructuring World Politics (Minneapolis: University of Minnesota Press, 2002): 3-23.

Kriesberg, Louis "Social Movements and Global Transformation," in, Jackie Smith, Charles Chatfield, and Ronald Pagnucco, eds., Transnational Social Movements and Global Politics (Syracuse: Syracuse UP, 1997): 3-18.

Naim, Moses, “What is a Gongo?” Foreign Policy, 160 (2007): 95-96.

Nayyar, Deepak, ed., Governing Globalization, (Oxford: Oxford UP, 2002).

Nelson, Paul, World Bank and Non-Governmental Organizations (NY: St. Martin's Press, 1995).

Nielson, Daniel and Michael Tierney, "Delegation to International Organizations," International Organization 57/2 (2003): 241-276.

Nye, Joseph, Paradox of American Power (New York: Oxford, 2003).

O’Brien, Robert, Anne Marie Goetz, Jan Aart Scholte, and Marc Williams, Contesting Global Governance (Cambridge: Cambridge UP, 2000). 
Ougaard, Morten and Richard Higgott, eds. Towards a Global Polity (NY: Routledge, 2002).

Pincus, Jonathan and Jeffrey Winters, eds. Reinventing the World Bank (Ithaca: Cornell UP, 2002).

Risse, Thomas, "Transnational Actors and World Politics," in Walter Carlsnaes, Risse and Beth Simmons, eds., Handbook of International Relations (London: Sage, 2002): 255-274.

Scholte, Jan, "Civil Society and Democracy in Global Governance," Global Governance, 8/3 (2002): 281?304.

Scholte, Jan, "Civil Society and the Legitimation of Global Governance," Center for the Study of Globalization and Regionalization, University of Warwick, Working Paper 223/07, March 2007.

Scholte, Jan, "Civil Society and IMF Accountability," Center for the Study of Globalization and Regionalization, University of Warwick, Working Paper 244/08, May 2008.

Sikkink, Kathryn and Jackie Smith, "Infrastructures of Change: Transnational Organizations, 1953-93,” in, Sanjeev Khagram, James Riker, and Sikkink, eds,. Restructuring World Politics (Minneapolis: University of Minnesota Press, 2002): 24-44.

Smith, Jackie, Charles Chatfield, and Ronald Pagnucco, eds., Transnational Social Movements and Global Politics (Syracuse: Syracuse UP, 1997).

St. Clair, Asunción, "World Bank as a Transnational Expertised Institution," Global Governance 12/2 (2006): 55-75.

Tan, Celine, "Reform or Reinvent? The IMF at a Crossroads," Global Governance 12/4 (2006): 507-22.

Tarrow, Sidney, Power in Movement (NY: Cambridge UP, 1998).

Wade, Robert, "Greening the Bank: The Struggle over the Environment, 1970-1995," in Devesh Kapur, John Lewis and Richard Webb, eds., The World Bank: Its First Half Century, Volume II : Perspectives (Washington, DC: Brookings, 1997): 611-734.

Wapner, Paul, "Governance in Global Civil Society," in Young, Oran, ed., Global Governance (Cambridge: MIT Press, 1997): 65?84.

Wilkinson, Rorden and Steve Hughes, eds., Global Governance (London: Routledge, 2002).

Willetts, Peter "Pressure Groups as Transnational Actors," in, Willetts, ed., Pressure Groups in the Global System (NY: St. Martin's Press, 1982): 1-27.

Woods, Ngaire, The Globalizers (Ithaca: Cornell UP, 2006). 
World Bank, "Annual Progress Report on World Bank-NGO Cooperation," (Washington: WB, 1988-2007).

World Bank, "Nongovernmental Organizations in World Bank-Supported Projects" (Washington: WB, 1999).

World Bank, "Issues and Options for Improving Engagement Between the World Bank and Civil Society Organizations," (Washington: WB, 2005). 